\title{
千葉県検見川人工海浜の変形機構について BEACH CHANGES AT KEMIGAWA ARTIFICIAL BEACH IN CHIBA PREFECTURE
}

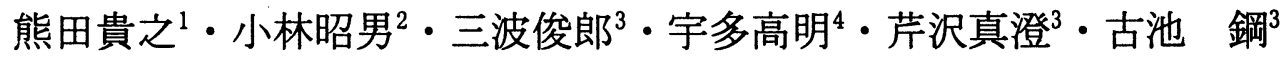 \\ Takayuki KUMADA, Akio KOBAYASHI, Toshiro SAN-NAMI, Takaaki UDA, \\ Masumi SERIZAWA and Kou FURUIKE
1学生会員 工修 日本大学大学院理工学研究科海洋建筑工学専攻（广274-8501 千葉県船橋市習志野台7-24-1） ${ }^{2}$ 正会員 工博 日本大学専任講師 理工学部海洋建築工学科（同上）
3海岸研究室（有）（厂160-0011 東京都新宿区若葉1-22 ローヤル若葉208）
${ }^{4}$ 正会員 工博 国土交通省土木研究所河川部長（テ305-0804 茨城県つくば市旭1）

\begin{abstract}
Beach changes at the Kemigawa artificial Beach in Tokyo Bay were investigated based on field surveys. Beach nourishment was conducted and the shoreline paralell to the seawall was formed. In order to enhance stability of nourished sand, curved groins were built at the south and north ends after the nourishment, forming wave calm zones in their lee sides. Large scale shoreline changes were triggered due to the construction. Beach changes were measured, and the changes in the beach profiles and the shoreline were studied. Comparison between the measured shoreline and that predicted by Hsu's model was made.
\end{abstract}

Key Words : Artificial beach, nourishment, shoreline change, aerial photograph, Kemigawa Beach

\section{1. まえがき}

近年, わが国では全国的に海岸侵食が進行し自然海浜 の喪失が続いている.こうした状況の一方で, 臨海部開発 に伴うミティゲーションや親水空間の創出を目的とした 人工海浜の造成もまた多く行われてきている.東京湾に 面した検見川浜もその一つであり，両端を突堤で囲まれ た延長 $1,300 \mathrm{~m}$ の区域で養浜が行われた. しかし養浜後侵 食が進み護岸前面に高い浜崖が形成され，折角建設され た人工海浜であるにもかかわらず, 海岸利用上望ましく ない状況となっている. 特に海浜中央では侵食が激しく, 現在では遊泳・立ち入り禁止措置が取られている.この ことから検見川浜では安全な海浜に戻すための有効な措 置が望まれている. しかしながら, 従来検見川浜の詳細な 海浜変形特性は明らかにされておらず,有効な侵食対策 の立案のためにはまず侵食の実態を明らかにすることが 必要である.このことから, 本研究では前報”に続き, 検 見川浜で現地踏查, 海浜地形測量, 海浜砂の材料調查など を行うとともに, 空中写真の判読による汀線変化分析, お よび実測汀線と修正Hsuモデル2)による予測汀線との比 較を行った。

\section{2. 検見川浜の概要}

検見川浜は図-1に示すように東京湾最奥部に位置す る. 検見川浜で海岸線に立てた法線の方向はSWである. 当 海岸の風向特性として, 年間の最多風向はNNW（出現率 11.9\%) であり,SSW（10.9\%）, NNE（9.7\%）がそれに次ぐ. 風速はSSW時に最も速い ${ }^{33}$.

人工海浜の造成は1977年に開始され1991年に完成した 3). 图-2（a)，(b)に示すように人工海浜の両端には先端 部が円弧状の曲突堤が, また沖合には養浜砂流出防止用 の潜堤が設置され,さらに海浜中央には小突堤が設置さ れた. 海浜の沿岸方向の長さは $1,300 \mathrm{~m}$, 岸沖方向の砂浜幅 は満潮時で $50 \mathrm{~m}$, 平均潮位時で $80 \mathrm{~m}$ であった。曲突堤は鋼管 矢板式で長さは593mである.潜堤は石積み堤でその長さ は1,300mである. 養浜砂の中央粒径（ $\left.d_{50}\right)$ は0.162mmで, 養浜総土砂量は $1.23 \times 10^{6} \mathrm{~m}^{3}$ であり, 海浜の初期勾配は 1/20であった.

しかしながら養浜の完成と同時に侵食が始まり, 1993 年には顕著な浜崖が形成された. 1995年以降侵食対策と して海浜中央の北側 $150 \mathrm{~m}$ の位置にY字突堤が建設されて いる. 


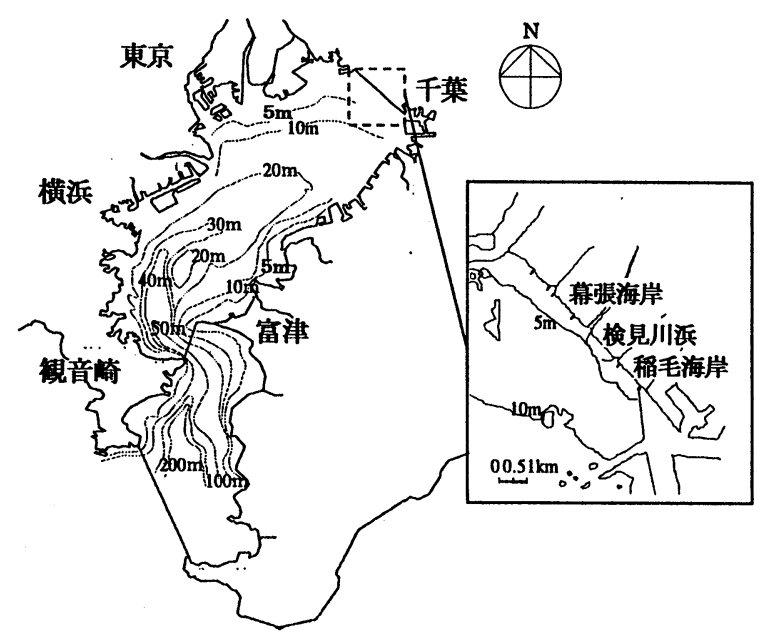

图-1 検見川浜の位置

(a) 計画平面図

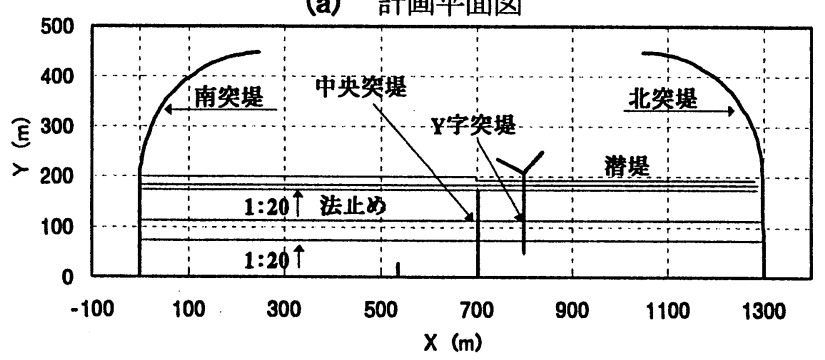

(b) 計画断面図

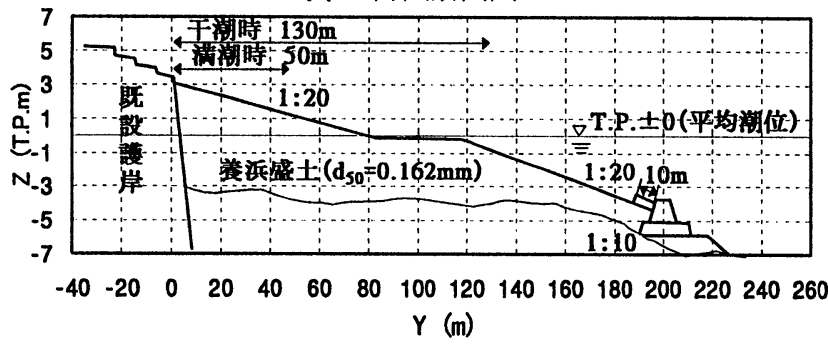

图-2 検見川浜の概略図

\section{3. 空中写真の汀線変化}

検見川浜の過去の海浜変形過程を把握するために, 空 中写真よりまず大スケールでの海浜状況の変化を判読し た. 検見川浜では（株）京葉測量撮影により毎年1回空中 写真が撮影されてきているが, 以下では全体で13枚の空 中写真より3枚を選んで写真判読を行う.なお, 空中写真 による汀線変化解析では1987〜1999年に撮影された全て の写真を用いることとする.

写真-1には1987年の空中写真を示す.この段階では突 堤先端の曲部は建設されておらず海岸線は直線状であっ た. 養浜汀線は護岸線と平行に設定されたが, 波の入射方 向が平均汀線への法線方向よりわずかに時計回りの方向 に傾いていたため, 南突堤付近の汀線は北突堤付近より も若干前進している.

写真-2は1993年の空中写真である. 突堤先端の曲部が 完成し,それに伴って突堤付け根付近の汀線が前進し海 浜中央部では後退した.このような汀線変化は，曲突堤に より波の遮蔽域が形成されたために, 波の遮蔽域外から
遮蔽域内に向かう沿岸漂砂が生じたことによる.

写真-3に示す1999年の空中写真では汀線変化が更に 顕著となった. 海浜中央に設置されていた養浜砂安定化 のための小突堤が撤去され，海浜中央より北側150mに新 たにY字突堤が建設されつつある. それに伴い汀線は建設 中のY字突堤の付け根では1993年に比べて前進し, Y字突 堤の両側のやや離れた場所では後退した. また, 曲突堤の 付け根ではさらに前進していることが分かる.

検見川浜における1987〜1999年撮影の空中写真から各 年の汀線形状を読み取り, 潮位補正を行って1987年を基 準とした各年の汀線変化量 $(\Delta \mathrm{Y})$ を算出した. 結果を 図-3に示す.なお, 後述する前浜測量データをもとに M. W. L. 時の汀線位置に補正した.

1999年の $\Delta Y$ を見ると $X=710 \mathrm{~m} ゙$ $\Delta Y=-34.6 \mathrm{~m}$ と, 最大の汀 線後退量を示す.この汀線後退量は初期海浜における平 均潮位時の海浜幅 $80 \mathrm{~m} の 43 \% に も$ 達する量であった.これ と対照的にX=1, 290mでは90.6mも汀線が前進している. ま た汀線変化量 $(\Delta \mathrm{Y})$ に海岸線の分割幅 $(\Delta \mathrm{X})$ を乗じて 1999年の侵食域と堆積域の面積 $A_{1}, A_{2}$ を算定すると,それ ぞれ $A_{1}=1.6 \times 10^{4} \mathrm{~m}^{2}, \mathrm{~A}_{2}=2.2 \times 10^{4} \mathrm{~m}^{2}$ となった。

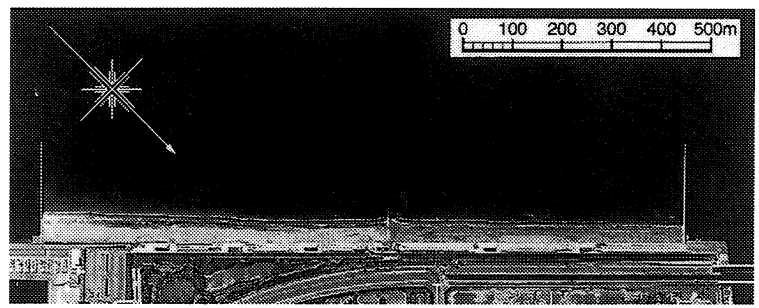

写真-1 検見川浜の空中写真（1987年）

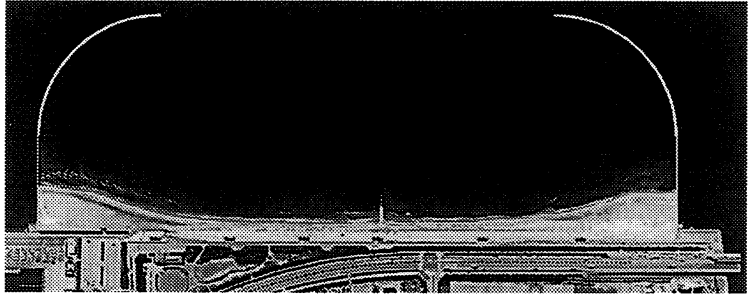

写真-2 検見川浜の空中写真（1993年）

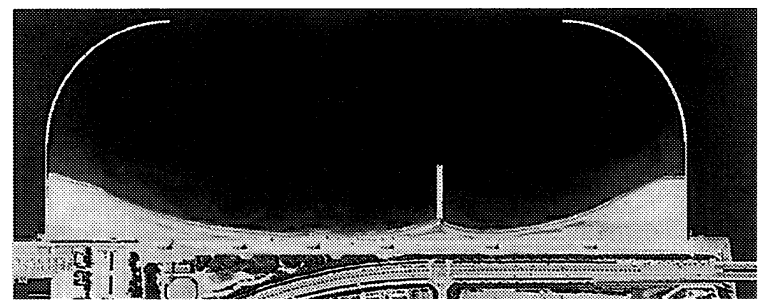

写真-3 検見川浜の空中写真（1999年）

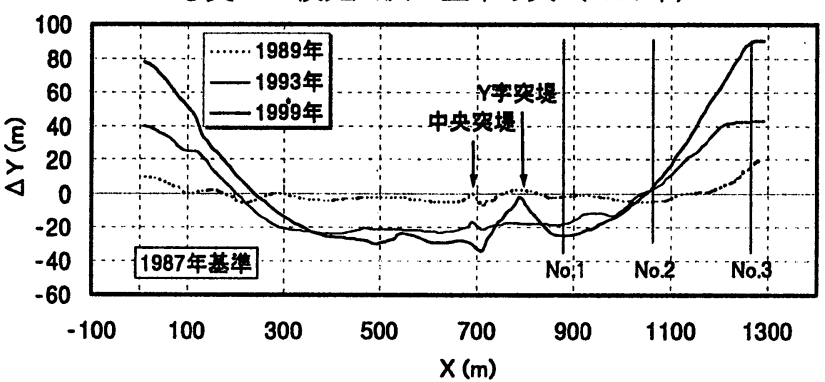

图-3 1987年を基準にした汀線変化量 
図-4は, 図-3に測線位置を示すように, 侵食域のNo. 1， 侵食も堆積も起きていない中立位置のNNo.2, 堆積域の No. 3の汀線変化量 $(\Delta \mathrm{Y})$ の時系列変化である. N0.2の $\Delta$ Yは測定年によって若干変動はあるものの大きな変化は ない.これに対しNo.1では $\Delta Y$ 経年的に减少し, No. 3で は顕著に増大している.これらの長期的トレンドとは別 に, №. 1 とNo. 3 $\Delta \mathrm{Y}$ には顕著な 1 年の周期変動が見られ る.すなわちNo. 3で汀線が前進した時にNo. 1で後退する という特性が見られる. 場所的に対照的な位置にある No. 1 とNo. 3で逆モードの汀線変化が生じるためには, 波 向の周期変動が存在しなければならない.そして図-4に 示したように侵食域での汀線後退と堆積域での汀線の前 進が同時に進行していることは,このような変形が沿岸 漂砂起源であることを強く示唆していると考えられる. また, 図一4によれば汀線はまだ安定形状に到達しておら ず, 今後も汀線変化が継続する傾向にある.

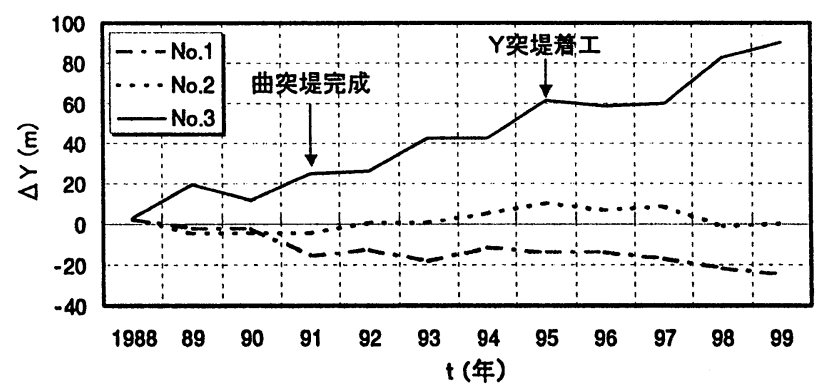

图-4 汀線変化量の経時変化

\section{4. 海浜の現地踏查}

2000 年10月 9 日, 海浜の侵食状況を調查するために現 地踏查を実施した. 現地踏查では, 海浜を北側から南側人 と汀線に沿って移動しつつ調べた. 海浜の南北両端に設 置された曲突堤は釣り栈橋を兼ねており, 突堤上に上が ることができる. 写真-4は北突堤上において突堤の付け 根方向を撮影したものである. 向かって右側に海浜が広 がっている.注目されるのは突堤上に砂が堆積し,さらに 砂が右側で厚く, 左側ではほとんど堆積していないこと である.これは手すりの右側に広がる海浜から飛砂に よって突堤上へと砂が運ばれてきていること, そして海 浜砂の一部はSSWの風によって飛砂となって海浜区域か ら失われていることを示している.

写真一5は突堤上から南側の海浜を撮影したものであ る.この位置から南側の海浜では沖向きに凸な形状の汀 線が形成されており, またバーム上には数本の満潮時汀 線の縞模様が見られ, その背後にはほぼ平坦な面が広 がっている.このことは, この平坦面が波の作用で土砂が 堆積して形成されたものであることを示している. なお, 写真中央やや左側に見える白い建築物は検見川市民病院 である.

写真一6はさらに市民病院に接近して海浜状況を撮影 したもので, 中央には病院の施設が大きく写っている. 汀
線は, 写真中央付近から大きく湾曲し背後地一と離れて いく.この付近の汀線形状は写真-5と異なり全体に凹状 である.ここでも汀線に沿ってバームが形成されており, その陸側にはやや標高の低い土地がある. 写真中央付近 より手前は汀線が前進した区域, 遠方は汀線の後退区域 であって, 写真中央は汀線が前進も後退もしていない中 立断面(図-3の測線No. 2) がある場所である.

写真-7は, 写其-6では中央やや右に写されていた休覟 所に接近して撮影したものである.海岸護岸と平行に延 びた養浜区域において浜崖が形成されている.この付近 は汀線が最も後退した場所であり,そこでは越波が激し いために写真-8のように海岸線に沿って連続的に消波 ブロックが置かれている. 消波ブロック背後の浜崖の高 さは約 $1.8 \mathrm{~m}$ に達し, 造成值後の土砂が著しく削り取られ

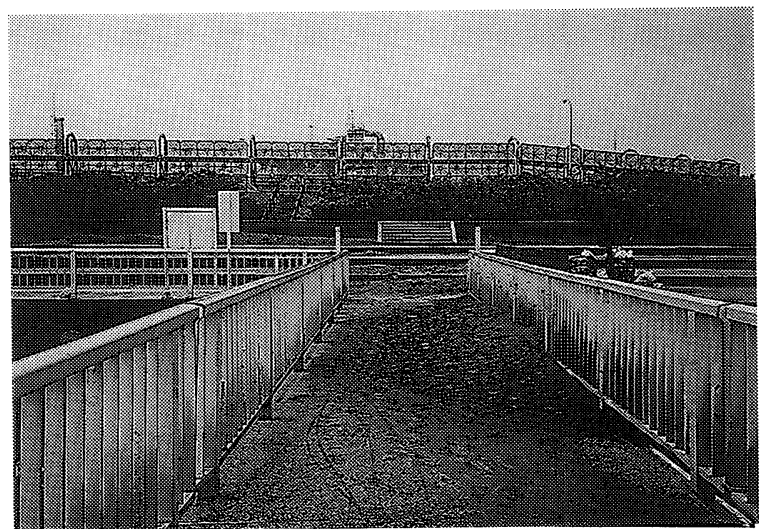

写真-4 北突堤上における飛砂による土砂の堆積状況

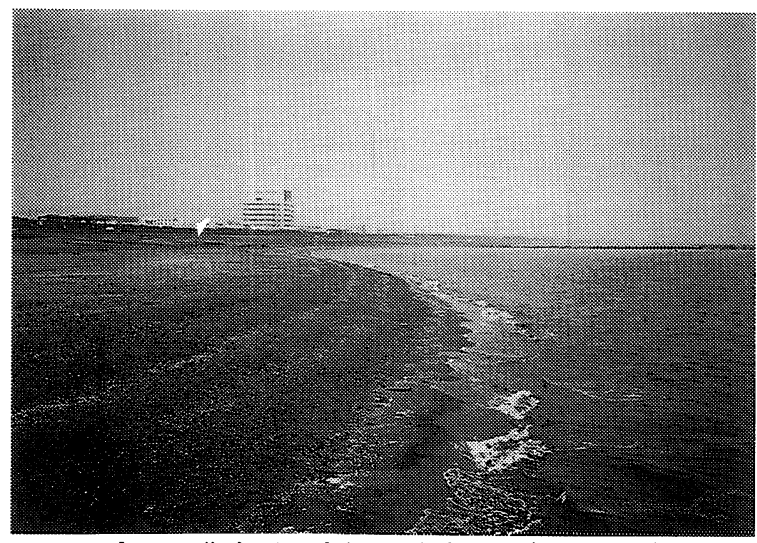

写真-5 北突堤の南側で堆積して広がった砂浜

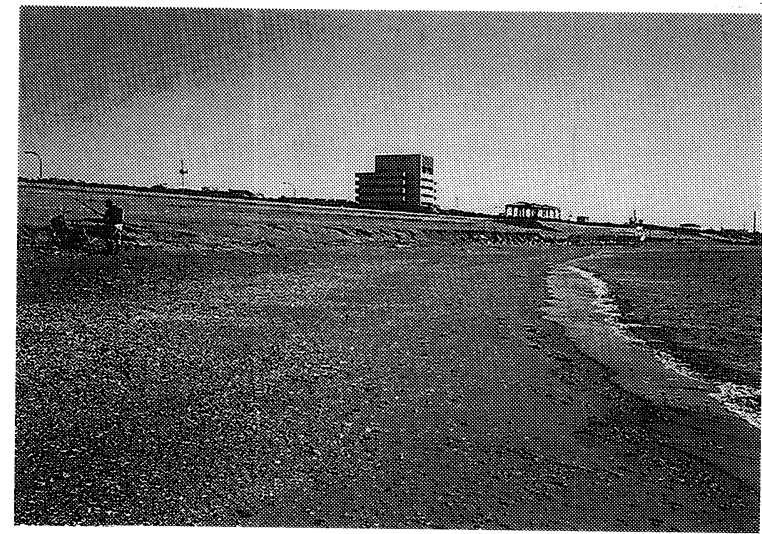

写真-6 侵食・堆積域の境界付近の海浜状況 
たことが分かる. 侵食土砂の大部分は写真-5に示す北突 堤に隣接する堆積域へと運ばれたと考えられる.

写真-9は写真-8よりもさらに南側で撮影したもので, 直立護岸の表面に残された模様より判断すると, ポール で示す位置まで土砂が被さっていたが, それが運び去ら れたことを表している. 写真-9に示す状況はその南側で も同様に続いており,護岸下部には消波ブロックが連続 的に設置されている.

写真-10は写真-9の撮影地点付近から南側を望んだも ので, 護岸と直交方向に見えるのはポケットビーチの中 央やや北側に建設されたY字突堤である.さらに写真-11 は侵食が最も激しい区域から北側を撮影したものである. 写真手前側では, 直立護岸の前面に造成した平坦な面は 完全に侵食され消失しているが, その前方ではこの平坦 面が一部残されている.

写真-12は, 海浜中央のY字突堤の背後で汀線がやや前 進している区域の海岸状況を撮影したものである.ここ では一部前浜が広がっているが,これはまず字突堤が存 在しない時期に大きく削られて浜崖が形成されたが, そ の後Y字突堤の付け根部分では波の遮蔽域が形成され, 局 所的に汀線が前進したことを表している.

\section{5. 海浜測量}

2000年11月15日,海浜形状を定量的に把握するために 海浜地形測量を行った. 図-2(a)に示したように, 海浜の

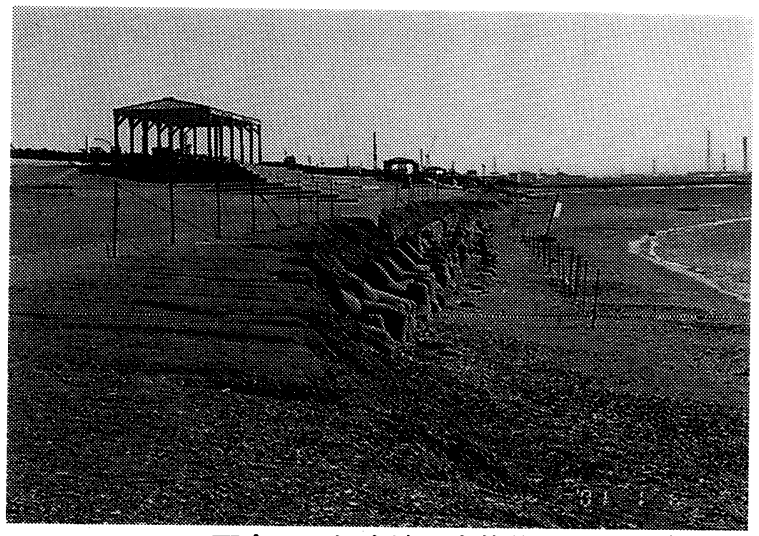

写真-7 侵食域の全体状況

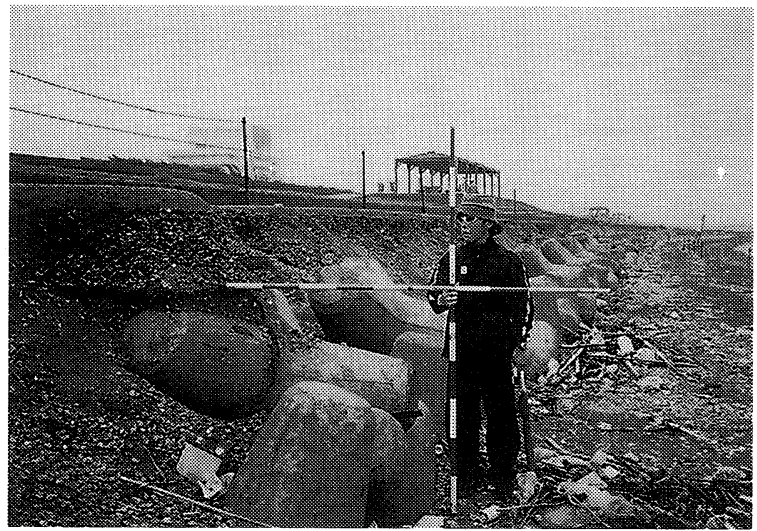

写真-8 侵食域における浜崖形成状況
中央付近（沿岸方向距離 $X=625 \mathrm{~m}$ ) から北突堤付け根付

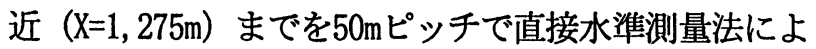
り測量した. 同時に同じ測線上で前浜砂を採取した. 図一

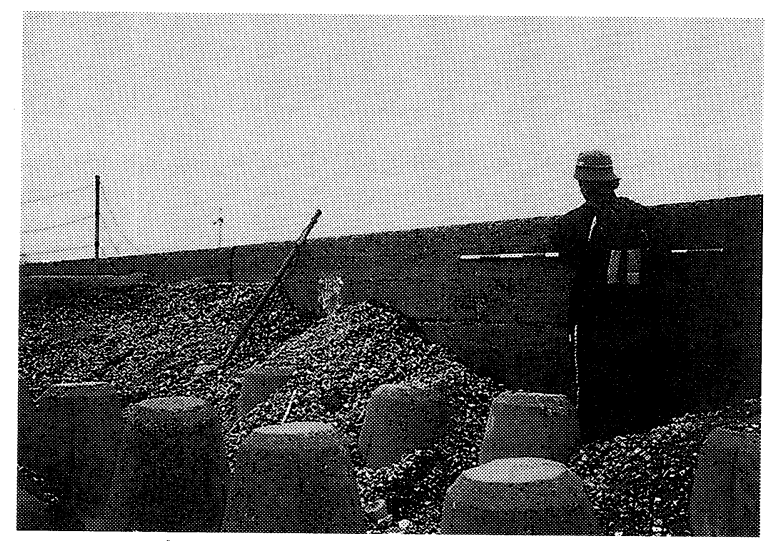

写真-9＼cjkstart直立護岸に残された盛土の高さ

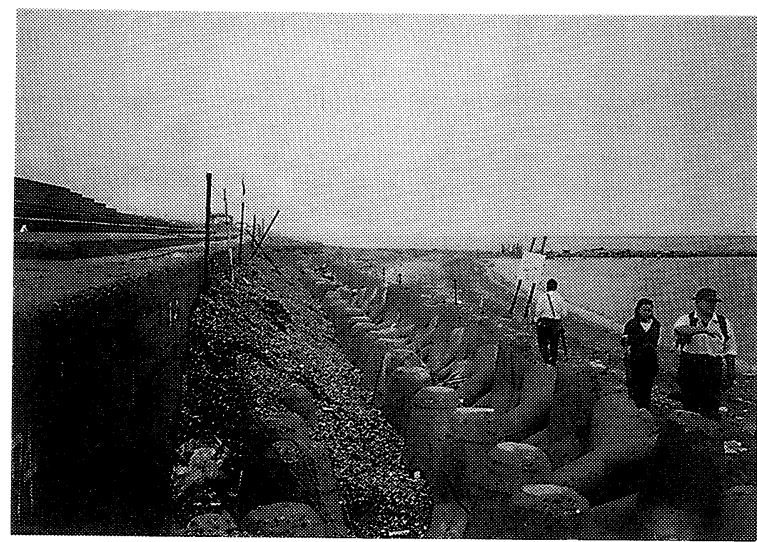

写真-10 侵食域と中央の小突堤

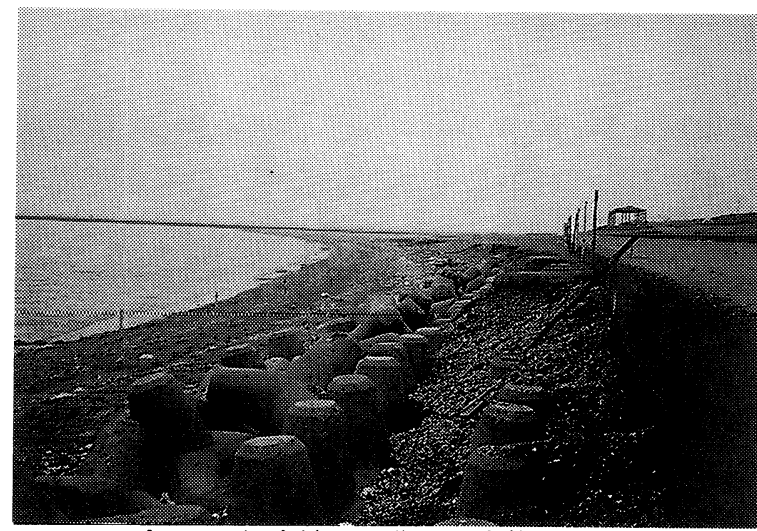

写真-11 侵食域から北側の全体状況を望む

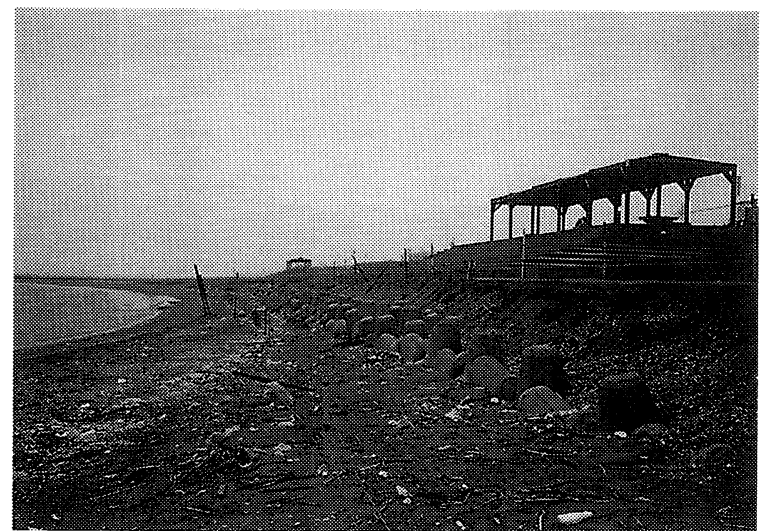

写真-12 小突堤背後の海浜状況 
3に示した侵食域の測線NNo.1と, 中立断面の測線No. 2, 堆 積域の測線No. 3の海浜縦断形を重ね合わせて表示したの が図一である. 各測線の前浜勾配は約 $1 / 8$ とほぼ同一の 值を示し, 前浜付近の海浜断面は岸沖方向にほぼ平行移 動した特徴を示している. 検見川浜はもともと沿岸方向 にNo.2に近い断面形状でほぼ一様に養浜されたから, 測 線NNo.1では計画断面から約 $30 \mathrm{~m}$ 陸側へ汀線が後退し, 堆積 域のNo. 3では約90m前進したことを示している.

図一は前浜勾配 $(\tan \beta)$ と中央粒径 $\left(d_{50}\right)$ の沿岸方 向分布である. 前浜勾配は綐断測量データから算定し た. $d_{50}$ は採取砂を粒度分析して求めた. 汀線後退域 (X= 925 975m) では前浜勾配が大きく,かつ $d_{50}$ が大きい.こ れに対し既設中央突堤およびY字突堤（X=675〜825m）, 北突堤付け根（X=1,175〜1,275m）など汀線前進域では 前浜勾配が小さく,かつ $d_{50}$ が小さいという特徽がある.

図一7は各測点における粒度分析結果をもとに砅, 粗砂, 細砂の含有率をまとめたものである. 图一において相対 的に $d_{50}$ の大きい侵食域 $(X=925 \sim 975 \mathrm{~m})$ では, 粗砂・䃇 の含有率が $25 \%$ と高いのに対し, 堆積域（X=675〜825m, $1,175 \sim 1,275 \mathrm{~m})$ では粗砂・碩の含有率は $10 \%$ 末満と低 い特徴が現れている.

以上のことから, 検見川浜は曲突堤の建設に伴い沿岸 漂砂移動が起こり, 侵食域では主として細砂が流出して 粗砂が残され，堆積域では細砂が堆積し，これに応じて前 浜勾配が定められたと考えられる. 前浜勾配と $d_{50}$ の関係 を線形回帰すると式(1)の関係が導かれる. 決定係数

$\left(\mathrm{R}^{2}\right)$ は0.944であり両者の間に高い相関があることが 分かる (図-8参照).

$$
\tan \beta=0.286\left(d_{50}\right)^{0.533}
$$

前浜勾配に関する従来の研究4) 5) 6) では, 前浜勾配は底 質粒径だけではなく入射波高, 周期に依存していること が指摘され, Sunamura ${ }^{7)}$ はこれらのパラメータを用いて 前浜勾配の予測式(2)を与えた.

$$
\tan \beta=0.12\left(H_{b} /\left(g^{1 / 2} T d_{50}{ }^{1 / 2}\right)\right)^{-1 / 2}
$$

ここに, $\mathrm{H}_{\mathrm{b}}$ とTは砕波波高と周期である. 式(1)の関倸は, 沿岸方向の土砂移動の結果として求められたものである. これに対し式(2)は局所的に岸沖方向の漂砂によって前 浜で侵食・堆積が起こる場合に得られた関係である. 両 者を比較すると, 粒径のべき数が式(2)では0.25であるの に対し,式(1)では0.53であり，検見川浜で得られた式(1) のほうが粒径への依存性が強く, 波浪条件への依存性が 低いことが分かる.

\section{6. 安定汀線に関するHsuモデルの適用}

検見川浜は曲突堤により波の遮蔽域が形成されたため に, 波の遮蔽域外から遮蔽域内へ向から沿岸漂砂が発生 し，海浜の中央が侵食されたと考えられる. 图-4に示し た $\Delta \mathrm{Y}$ 経時変化によると汀線はまだ安定形状に達して いないため, 海浜中央部はさらに激しく侵食されると考
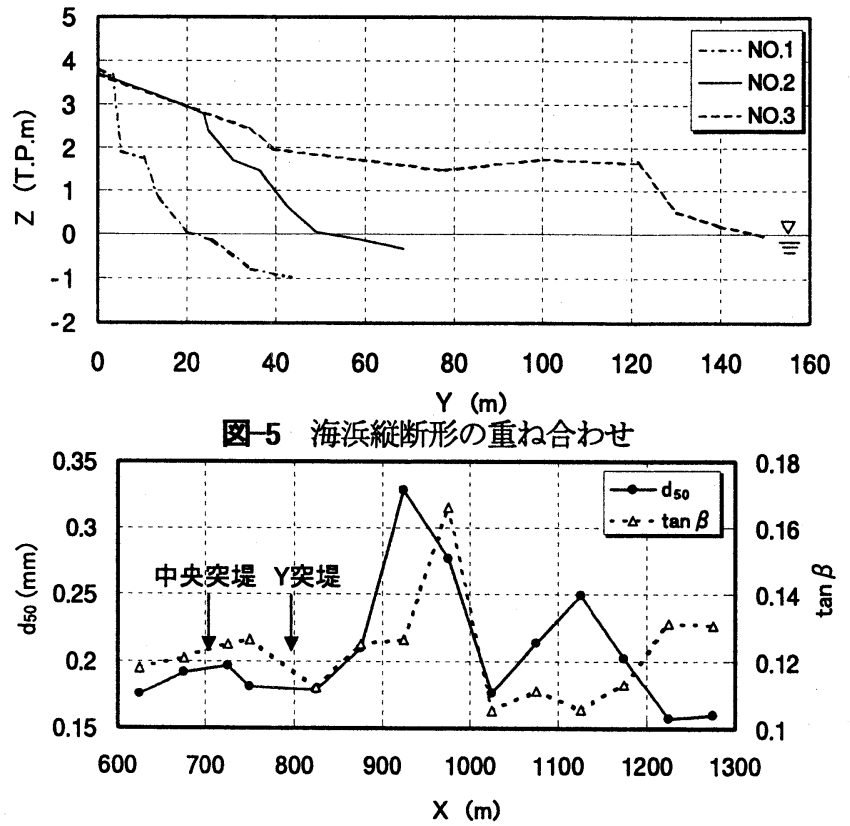

图-6 $\tan \beta$ と $d_{50}$ の沿岸方向分布

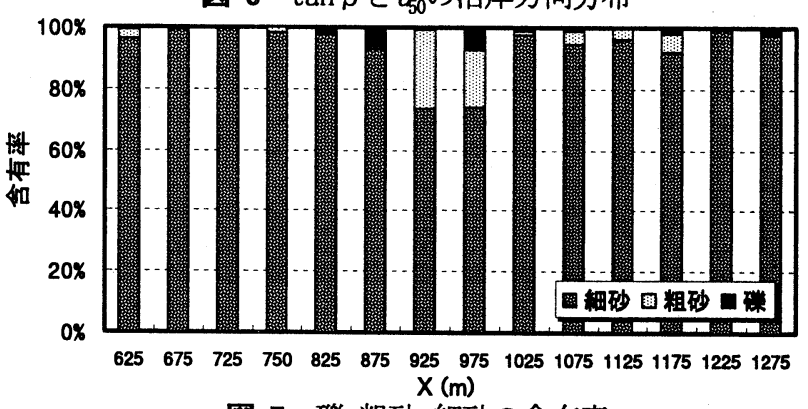

图-7 碰, 粗砂, 細砂の含有率

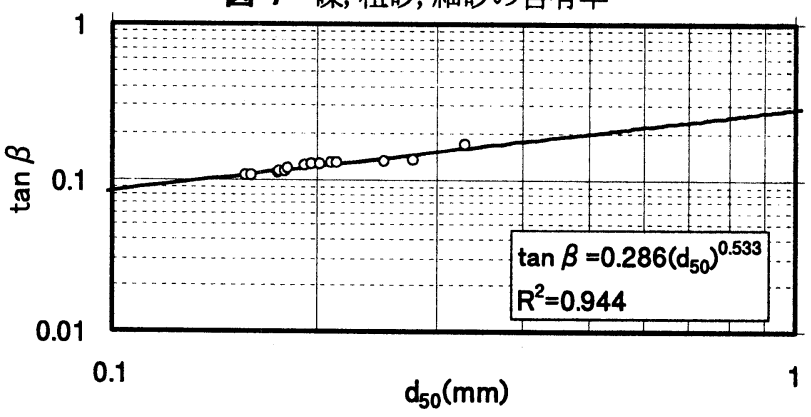

图-8 $\tan \beta$ と $d_{50}$ の関係

えられる. そこで将来の安定汀線形状を予測した. 安定汀 線形状の予測には, 極座標表示の汀線形状に関して2次の オーダーまでの回帰分析により直接的に汀線形状を求め, 土砂収支および境界条件を満足させた修正Hsuモデル2) を使用した. 計算はY字突堤がない場合 (ケース1) とY字 突堤を考慮した場合 (ケース2) である. 初期汀線は, ケース1では1987年とし,ケース2では1999年とした.

ケース 1 の計算結果を图-9に示す. 計算結果によると 海浜両端部の汀線が沖向きに前進し, 海浜中央部では汀 線が後退する.この場合, 汀線変化の不動点は图-3に示 した実測值とよく一致している. 初期汀線からの最大汀 線後退量はX=647m で $98 \mathrm{~m}$, 最大汀線前進量はX $=1,259 \mathrm{~m}$ 286mとなり, 実態のほぼ2倍の変化である.これは, 予測結 果が安定形状であるのに対して, 現況汀線はその変化途 中にあるためと考えられる.なお, 計算結果によると現況 
汀線は約27年後（2027年）に安定形状になると予測され る. したがって計画時の直線状汀線で護岸の露出を防ぐ には, 曲突堤の建設時に少なくとも護岸から約 $50 \mathrm{~m}$ 以上岸 側に汀線が後退可能なスペースが必要であったと考えら れる.

同様にケース2の計算結果を图-10に示す. 曲突堤の付 け根ではケース1と同様に汀線は1999年に比べ194m前進 し, Y字突堤付け根では23m前進した. 汀線はX=958mで, 直 立護岸より岸側に11m後退し, 汀線変化の不動点は実態よ りも曲突堤方向に $70 \mathrm{~m}$ 移動した. 直立護岸より岸側まで後 退した侵食域（X=900〜 $1,000 \mathrm{~m})$ では，現地調查によると 浜崖の形成が進み, 護岸に砂がほとんどついていないこ とから, 計算と害態がほぼ対応を示していると考えられ る. ケース 1 と比較すると, Y字突堤が建設されたことに よって最大汀線後退量は $40 \mathrm{~m}$ 軽減され, 海浜中央の侵食対 策として有効であることが分かる. しかしX=900〜 $1,000 \mathrm{~m}$ には新たに侵食域が形成されるので追加養浜の必要があ ると考えられる.

今後Y字突堤が完成したとしても侵食域は形成される ため, 養浜土砂が更に必要となる. その場合, 新たな購入 砂で養浜するのではなく, 曲突堤付け根付近の舌状砂州 上で通常時には波の作用の及ばない区域の砂を採取し, 侵食域に養浜する方法が考えられる. 曲突堤付近で, 現況 で波の作用の及ばない植生範囲（X=1,050 1,300m）の 面積に陸上部の標高 $1.5 \mathrm{~m}$ を乗じると $1.4 \times 10^{4} \mathrm{~m}^{3}$ の砂の採 取が可能である. 砂を採取した部分は通常の粘性土と入 れ替えれば植生の繁茂にも有効である.

\section{7. まとめ}

検見川浜を対象とした種々の現地調査結果は以下に要 約される.

(1)海浜測量結果によると, 各測線の前浜勾配は約 $1 / 8$ とほ ぼ同一の值を示し,海浜縦断形は岸沖方向にほほ半行移 動していることが分かった. また侵食域の汀線は建設当 初より約 $30 \mathrm{~m}$ 後退し, 堆積域では約 $90 \mathrm{~m}$ 前進したことが分 かった.

(2)粒度分析結果によると,検見川浜は曲突堤建設に伴い 侵食域では沿岸漂砂移動が起こり主として細砂分が流出 し粗砂分が残された. 対照的に堆積域では細砂分が堆積 し,これに前浜勾配が応じていることが示された. 前浜勾 配と $d_{50}$ の間には $\tan \beta=0.286\left(d_{50}\right)^{0.533}$ の関係が導かれ, 前 浜勾配は $d_{50}$ に高く依存していることが分かった.

(3)空中写真に基づく汀線変化解析結果によると, 侵食域 での汀線後退と堆積域での前進が同時に進行しているこ とから,検見川浜は海浜変形が主として沿岸漂砂によっ て支配されることが分かった.また, 養浜後14年が経過し た現段階の汀線はまだ安定形状に到達しておらず, 今後 汀線が安定形状に達するまで変化が続くと考えられる. 計算結果によると, 海浜中央のY字突堤がなかった場合の

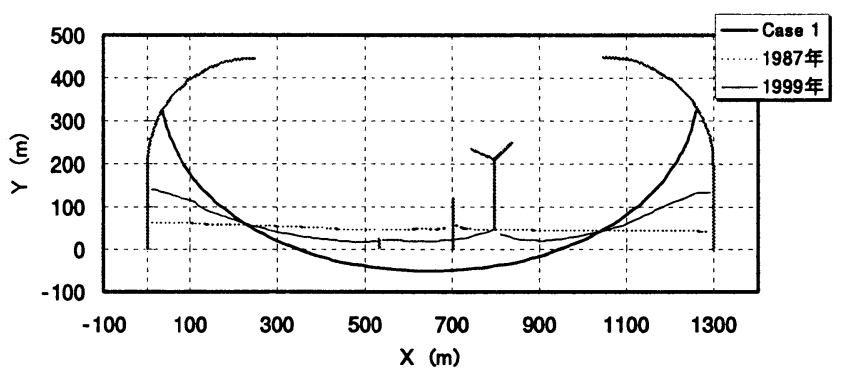

图-9 Y字突堤がない場合の安定汀線形状

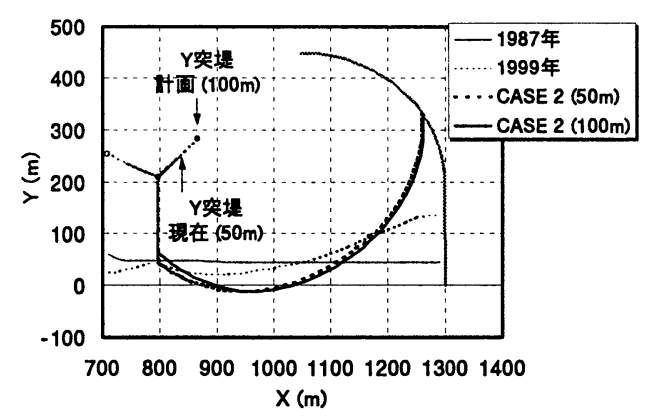

图-10 Y字突堤を考慮した場合の安定汀線形状

汀線は2027年には現況の約2倍の汀線前進・後退で安定 することが示された. したがって計画時の直線状汀線で 護岸の露出を防ぐには, 曲突堤の建設時に少なくとも護 岸から約50m以上岸側に汀線が後退可能なスペースが必 要である. 新たな養浜砂には, 曲突堤付け根付近の舌状砂 州上で通常時には波の作用の及ばない区域の土砂を利用 することが有効なことが示された.

謝辞 : 本研究の実施に際し, 検見川浜の波浪観測記録及 び深浅図などの貴重なデータを提供して頂いた千葉県土 木部港湾整備課主任技師の野村拓司氏および千葉県千葉 港湾事務所建設課長の児安哲司氏に深く感謝の意を表し ます。

\section{参考文献}

1) 熊田貴之, 小林昭男 : 検見川浜を対象にした人工海浜の侵 食過程に関する研究, 海洋開発論文集, 第16巻, pp. 315$320,2000$.

2) 芹沢真澄, 宇多高明, 三波俊郎, 古池鎆, 神田康嗣 : 修正 HSUモデルによるヘッドランド周辺の最適安定海浜形状の計 算法, 海岸工学論文集, 第43巻, pp. 646-650, 1996.

3）（財）沿岸開発技術研究センター: 検見川の浜数值解 析，千葉県海岸環境整備委託委員会報告書， 1993.

4) Bascom, W. N.: The relationship between sand size and beach-face slope, Am. Geophy. Union Trans., Vol. 32, pp. 866-874, 1951.

5) Wiegel, R. L.: Oceanographical Engineering, Prentice-Hall, Englewood Cliffs, New Jersey, 532p, 1964.

6) King, C. A. M.: Beaches and Coasts, Edward Amold, London, 570p, 1972.

7) Sunamura, T.: Quantitative predictions of beach-faces slopes, Geol. Soc. Am. Bull., Vol. 95, pp. 242-245, 1984. 